Avoimesti luettavissa osoitteessa http://journal.fi/ainedidaktiikka

ainedidaktiikka

\title{
Luonnontiedekasvatuksen muuttuvat tavoitteet: luonnontieteellisestä lukutaidosta kestävyys- kasvatukseen, toimijuuteen ja tulevaisuusajatteluun
}

Antti Laherto

Kasvatustieteellinen tiedekunta, Helsingin yliopisto

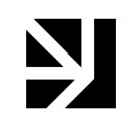

Globaalit ympäristö- ja kestävyyskriisit muuttavat luonnontiedekasvatuksen tavoitteita, didaktiikkaa ja tutkimusta. Luonnontieteellisen lukutaidon (engl. scientific literacy) merkitys kytketään yhä useammin transformatiiviseen kestävyyskasvatukseen. Siinä ei riitä, että koulussa opitaan luonnontieteen sisältötietoa tai sen käyttämistä arjessa, vaan luonnontiedekasvatuksen pitää lisäksi tukea vastuullista toimijuutta ja arvopohjaista muutosta sekä yksilöissä että yhteiskunnassa. Artikkelissa argumentoidaan, että tulevaisuudentutkimuksen ajattelutapoja hyödyntämällä on mahdollista tukea vaihtoehtojen ja vaikutusmahdollisuuksien näkemistä ja niihin tarttumista. Luonnontieteiden opetus tarjoaa hyvän alustan skenaarioajattelulle, tulevaisuuden epävarmuuden kohtaamiselle ja uudistavan toimijuusorientaation rakentamiselle. Ehdotuksia konkretisoidaan esittelemällä I SEE -projektissa kehitettyä tulevaisuusorientoitunutta luonnontiedeopetusta. Lopuksi pohditaan ehdotusten ajankohtaista merkitystä kestävyysongelmien ja COVID19-pandemiankin aikoina.

Luonnontiedekasvatus, kestävyyskasvatus, tulevaisuusajattelu, toimijuus

Lähetetty: 1.5.2020

Hyväksytty: 18.10.2020

Vastuukirjoittaja: antti.laherto@helsinki.fi

DOI: $10.23988 /$ ad.91998 


\section{Johdanto}

Maailmanlaajuisten ympäristö- ja kestävyyskriisien vauhdittamina myös luonnontiedeopetuksen teoria ja käytäntö - ainedidaktinen tutkimus, opetussuunnitelmat ja pedagogiikat - ovat alkaneet ottaa uusia suuntia. Sekä ainedidaktiikka että kansainväliset opetussuunnitelmasuositukset (esim. European Commission, 2015) ovat jo pitkään siirtäneet painotustaan luonnontieteen sisältöjen ja käsitteiden oppimisesta kohti taitojen ja kompetenssien oppimista (Kokkonen \& Laherto, 2018; Roberts \& Bybee, 2014). Tätä maailmanlaajuista trendiä heijastelee tieteellisen lukutaidon (scientific literacy) (esim. Roberts \& Bybee, 2014) merkityksen muuttuminen. Siinä missä vielä muutama vuosikymmen sitten termillä tarkoitettiin lähinnä luonnontieteen käsitteellistä osaamista, nykyään varsinkin kehittyneissä länsimaissa se ymmärretään kansalaistaitona: kykynä käyttää tieteellistä tietoa arjen ja yhteiskunnan asioissa ja tilanteissa. Nyt ilmastonmuutoksen ja sen globaalien vaikutusten ymmärryksen myötä nämä luonnontiedekasvatuksen kompetenssitavoitteet ovat varsinkin viime vuosikymmenen aikana alkaneet painottua kestävyyskasvatukseen (Education for Sustainable Development, ks. Unesco, 2017) ja "kestävyystaitoihin" (Wiek, Withycombe \& Redman, 2011), joita kansalaiset tarvitsevat osatakseen tarttua kestävän kehityksen mahdollisuuksiin, osallistua muutokseen ja suhtautua tulevaisuuden epävarmuuteen. Luonnontieteiden didaktiikassa tällaiset taidot näkyvät esimerkiksi toimintakompetenssin (action competence) ja yhteiskunnallisten kysymysten (socio-scientific issues, SSI) korostumisena tutkimuksessa ja opetussuunnitelmissa (Hodson, 2003; Mogensen \& Schnack, 2010; Zeidler, Sadler, Simmons \& Howes, 2005). Lasten ja nuorten vastuullisen toimijuuden (agency) tukemisesta on tulossa yhä laajemmin hyväksytty luonnontiedekasvatuksen päämäärä (European Commission, 2015; Hodson, 2003; OECD, 2018).

Yksilön tapa ajatella tulevaisuudesta kytkeytyy tiiviisti hänen kokemaansa toimijuuteen. Käsityksemme tulevaisuudesta vaikuttavat vahvasti siihen, minkälaisia mahdollisuuksia näemme vaikuttamiseen ja toimintaan (Carabelli \& Lyon, 2016; Cuzzocrea \& Mandich, 2016). Keskittyminen uhkakuviin kaventaa ajattelua, ja toivon näkökulma rohkaisee näkemään mahdollisuuksia (Lombardo \& Cornish, 2010). Vaihtoehtoisten skenaarioiden pohtiminen valmentaa kohtaamaan epävarman tulevaisuuden (Bishop, Hines \& Collins, 2007). Ilmastokriisin kontekstissa tällaiset kytkennät ovat näkyneet paljon puhutun ja tutkitun ilmastoahdistuksen vaikutuksissa yksilön kokemaan toimijuuteen (Ojala, 2012; Tolppanen, Aarnio-Linnanvuori, Cantell \& Lehtonen, 2017).

Tässä artikkelissa argumentoidaan, että kestävyyskasvatukseen orientoituneessa ja toimijuutta vahvistavassa luonnontiedeopetuksessa on sekä tarve että tilaisuus harjoitella tulevaisuusajattelua. Artikkelissa luonnontiedekasvatus ja luonnontiedeopetus määritellään laajassa science education -merkityksessä, joka kattaa oleellisesti myös teknologian roolin yhteiskunnassa ja arjessa (vrt. Laherto, 2010; Roberts, 2007; Roberts \& Bybee, 2014). Tässä laajassa merkityksessä luonnontiedekasvatus tähtää 
sellaisiin tieteeseen ja teknologiaan liittyviin tietoihin, taitoihin ja valmiuksiin, joita ajatellaan kansalaisten tarvitsevan elämässään ja yhteiskunnassa. Luonnontiedekasvatusta toteutetaan kaikilla koulutusasteilla erityisesti luonnontieteiden oppitunneilla, mutta myös muiden oppiaineiden yhteydessä ja eri oppiaineita integroiden; esimerkiksi Suomessa peruskoulun monialaiset oppimiskokonaisuudet (Opetushallitus, 2014) ja lukion laaja-alaisen osaamisen tavoitteet (Opetushallitus, 2019) sisältävät luonnontiedekasvatuksenkin tavoitteita. Lisäksi luonnontiedekasvatuksen tavoitteita usein yhdistetään koulun ja koulutusjärjestelmien ulkopuolella tapahtuvaan oppimiseen (Laherto, 2013). Tässä artikkelissa tarkastellaan kuitenkin koulussa tapahtuvan luonnontiedekasvatuksen ja -opetuksen yleisiä, kansainvälisiä ja kaikkia koulutusasteita koskevia suuntauksia, päämääriä ja malleja.

Artikkelin aluksi esitellään, miten kestävyyskasvatuksen tavoitteet ovat 2010-luvulla nousseet kansainvälisesti luonnontiedeopetuksen ja -kasvatuksen fokukseen. Sen jälkeen käsitellään tulevaisuudentutkimusta ja perustellaan tulevaisuusajattelun kytkemistä toimijuuteen ja kestävyyskasvatukseen. Sitten perustellaan, miksi ja miten tulevaisuusajattelua ja toimijuutta edistetään juuri luonnontiedeopetuksessa. Esitettyjä ajatuksia konkretisoidaan esittelemällä lyhyesti eräässä tulevaisuudentutkimuksen menetelmiä luonnontieteiden opetukseen soveltavassa hankkeessa, EUprojektissa nimeltä I SEE, kehitettyjä didaktisia ratkaisuja ja referoidaan empiirisiä tuloksia siitä, miten lukio-opiskelijat nämä menetelmät kokivat. Artikkelin lopuksi pohditaan ehdotusten ajankohtaista merkitystä globaalien kestävyyskriisien maailmassa.

\section{Kestävyyskasvatus luonnontiedeopetuksen tavoitteena}

Globaalit ympäristö- ja kestävyyskriisit ovat kiihdyttäneet jo vuosikymmeniä jatkunutta luonnontiedeopetuksen tavoitteiden ja didaktiikan muuttumista. Perinteisen luonnontieteen sisältöjen hallinnan ohella opetuksessa on viime vuosikymmeninä yhä enemmän korostettu oppilaiden valmiuksia osallistua tieteeseen ja teknologiaan liittyvään keskusteluun ja päätöksentekoon henkilökohtaisissa, yhteiskunnallisissa ja globaaleissa kysymyksissä (Kokkonen \& Laherto, 2018). Roberts (2007) ja myöhemmin Roberts ja Bybee (2014) ovat kuvanneet tätä luonnontiedekasvatuksen tavoitteissa tapahtunutta muutosta siirtymänä visiosta I visioon II. Näistä ensimmäinen katsoo "sisäänpäin" tieteeseen, sen prosesseihin ja sisältöihin, kun taas jälkimmäinen katsoo tilanteisiin, joita oppilaat kohtaavat kansalaisina. Vision II mukainen luonnontieteellinen lukutaito (engl. scientific literacy) on nykyään laajasti hyväksytty luonnontiedekasvatuksen päämäärä (Kokkonen \& Laherto, 2018). Tämä suuntaus näkyy esimerkiksi kansainvälisesti koulutusjärjestelmiin vaikuttavassa PISA-ohjelmassa (OECD, 2019), jossa luonnontieteellinen lukutaito käsitetään toiminnallisena osaamisena pikemmin kuin tietämisenä. Euroopan unioni on luonnontiedeopetusta koskevissa suosituksissaan korostanut yhteiskunnallisia kysymyksiä ja vastuullisuutta (European Commission, 2015; Rocard ym., 2007), ja viime vuosikymmenen aikana ohjannut luonnontiedeopetusta yhteiskunnallisemmaksi myös tuomalla Responsible Research and Innovation (RRI) -ajattelua eurooppalaisiin kouluihin 
(Apotheker ym., 2017; de Vocht \& Laherto, 2017; de Vocht, Laherto \& Parchmann, 2017).

Opetuksen tutkimuksen kentällä nämä painotukset näkyvät selvimmin siinä, että luonnontieteen ainedidaktiikan keskiöön on noussut koulussa opittavan tieteen autenttisuuden rinnalle sen relevanssi oppilaalle (Kapon, Laherto \& Levrini, 2018; Stamer ym., 2020; Stuckey, Hofstein, Mamlok-Naaman \& Eilks, 2013). Sen myötä tutkimusalaa ovat vallanneet kontekstiperustainen oppiminen (context-based learning, CBL) (esim. Gilbert, 2006), koulun ulkopuolella oppiminen (esim. Laherto, 2013; 2018; Lavonen ym., 2009) sekä varsinkin yhteiskunnallisten kysymysten käsittely luonnontiedeopetuksessa (socio-scientific issues, SSI; esim. Zeidler ym., 2005). SSI-viitekehyksessä kiinnitetään tyypillisesti huomiota oppilaiden arvolatautuneeseen dialogiin, argumentaatiotaitoihin ja ymmärrykseen monista kytköksistä tieteen, teknologian, yhteiskunnan ja ympäristön välillä. On huomattava, että sekä useimmat tutkijat että koulutuspolitiikan tekijät korostavat sitä, että myös tällainen visio II -tyyppinen tieteellinen lukutaito vaatii edelleen myös episteemistä ja käsitteellistä tieteenalakohtaista sisältöosaamista (esim. Kapon, Laherto \& Levrini, 2018; OECD, 2019; Roberts, 2007; Roberts \& Bybee, 2014). Visiossa II ja SSI-lähestymistavassa sisältöosaaminen yhdistyy muun muassa tieteen luonteen (Nature of Science) ymmärtämiseen (Erduran \& Dagher, 2014; Laherto ym., 2018) ja tieteellisen argumentaation taitoihin (Osborne, Erduran \& Simon, 2004). Tämä yhdistelmä nähdään yhä tärkeämpänä nyt totuudenjälkeisenä aikana (Higgins, 2016; van Poeck, 2019) ja COVID-19-pandemiakriisin sekoittaessa maailmanjärjestystä.

Edellä kuvatut kehityskulut ovat siis olleet käynnissä jo pidempään, mutta erityisesti 2010-luvulla globaalien kestävyyskriiseihin heräämisen myötä ovat kaiken kouluopetuksen tavoitteet joutuneet suureen muutospaineeseen. Kasvatus ja opetus ovat keskeisessä roolissa maailmanlaajuisessa pyrkimyksessä kohti kestävän kehityksen tavoitteita (Sustainable Development Goals, $S D G$ ), jotka Yhdistyneiden kansakuntien jäsenmaat sopivat Agenda 2030 -kehitysohjelmassa vuonna 2015. Kestävyyskriiseihin vastaamisen on sanottu vaativan perustavanlaatuista kasvatuksen ja koulutuksen arvojen ja tarkoituksen uudelleenajattelua sekä radikaalejakin muutoksia koulutusjärjestelmiin ja kasvatuksen lähestymistapoihin (Laininen, 2019; Lotz-Sisitka, Wals, Kronlid \& McGarry, 2015). Nämä vaatimukset ovat heijastuneet erityisesti kestävyyskasvatukseen (Education for Sustainable Development), joka myös määriteltiin yhdeksi Agenda 2030 -ohjelman keskeisimmistä tavoitteista (Unesco, 2017). Kestävyyskasvatuksella pyritään kokonaisvaltaiseen ja transformatiiviseen oppimiseen (Lotz-Sisitka ym., 2015). Transformatiivisuudella tarkoitetaan tässä vuorovaikutteista, yleensä toiminnallista ja oppijakeskeistä pedagogiikkaa, joissa tähdätään muutoksen aikaansaamiseen sekä oppijassa että yhteiskunnassa (Hodson, 2011). Koska kestävyyskriisit vaativat paradigman muutosta ja uutta tapaa ajatella (Laininen, 2019; Sharpe, Hodgson, Leicester, Lyon \& Fazey, 2016), kestävyyskasvatuksella pyritään auttamaan oppilaita näkemään vaihtoehtoisia tulevaisuuksia ja löytämään uusia tapoja ratkaista ongelmia kestävällä tavalla. 
Yhdistyneiden kansakuntien ja Unescon (2017) kanssa samansuuntaisia vaatimuksia on esittänyt myös Taloudellisen yhteistyön ja kehityksen järjestö OECD, jonka linjapaperissa The Future of Education and Skills asetetaan koulujen tehtäväksi valmentaa lapset ja nuoret sellaisiin ammatteihin, teknologioihin ja ongelmiin, joita ei vielä ole olemassa (OECD, 2018). Heidän on opittava luovimaan epävarmuudessa, toimimaan vastuullisesti ja edistämään yksilöiden, yhteisöjen ja planeetan hyvinvointia. OECD nostaa toimijuuden (agency) ominaisuudeksi, jota erityisesti tarvitaan tulevaisuuden kompleksisuuden ja epävarmuuden kohtaamisessa (OECD, 2018). Toimijuuden OECD määrittelee vastuulliseksi osallistumiseksi, jolla vaikutetaan ihmisiin, tapahtumiin ja olosuhteisiin niin, että muutos on parempaan suuntaan.

Näiden uusien, kestävyyskasvatusta ja toimijuutta korostavien suuntausten ja tavoitteiden toteuttamisessa on luonnontiedekasvatuksella erityinen rooli. Tiede ja teknologia läpäisevät kansalaisten arjen ja päätöksenteon nyky-yhteiskunnissa, teknologinen kehitys on kiihtyvää, ja ihmiset kohtaavat yhä enemmän tieteeseen ja teknologiaan liittyviä asioita. Kohdattavat asiat koskevat sekä henkilökohtaista elämää että yhteiskunnallisia ja globaalejakin kysymyksiä. Erityisen vahva luonnontieteellinen komponentti on ilmastonmuutoksella ja muilla kestävyyskriiseillä sekä niihin liittyvillä huolilla ja ratkaisuilla (Tolppanen ym., 2017). Kansalaisten luonnontieteellinen lukutaito onkin tullut keskiöön pohdittaessa vastauksia sekä globaaleihin kestävyysongelmiin että 2010luvun yhteiskunnallis-poliittiselle keskustelulle, jossa enenevästi siedetään perustelemattomia väitteitä, tosiasioiden kieltämistä ja tieteellisten konsensuksen kiistämistä ("totuudenjälkeinen aika", ks. esim. Higgins, 2016; van Poeck, 2019). Vuotta 2020 leimaava ja kansalaisten arkeen syvästi vaikuttava COVID-19-pandemia on entisestään korostanut kansalaisten tiedeosaamisen tärkeyttä ja sen puutteen ongelmallisuutta: ihmiset jäsentävät ymmärrystään pandemiasta luovien uutistulvassa, jossa tutkimustieto ja tieteelliset argumentit sekoittuvat monenlaisiin muihin väitteisiin, intresseihin ja kokemustietoon. Vaikka pandemian on ainakin hetkellisesti havaittu nostavan tieteen arvostusta ja siten palauttavan rationaalisuutta "totuudenjälkeiseen aikaan", on mediassa samaan aikaan kasvanut huoli siitä, että kriisin jälkeen muodostuu tilaa uudelle populismin aallolle (ks. esim. Sirén, 2020; Virtanen, 2020).

Edellisen vuosikymmenen aikana onkin erityisesti luonnontiedeopetukselle alettu vaatia edellä kuvattua visiota II refleksiivisempiä ja radikaalimpia tavoitteita. Tyypillistä SSI-opetusta sekä tiede-teknologiayhteiskunta-ympäristö -lähestymistapoja (Zeidler ym., 2005) on kritisoitu pinnallisiksi, poliittisesti naiiveiksi ja siksi tehottomiksi tarvittavan yksilöllisen ja yhteiskunnallisen muutoksen aikaansaamisessa (Hodson, 2011). Vallalla olevat kouluopetuksen lähestymistavat eivät nosta esiin saati kyseenalaista tieteen ja koulutusjärjestelmien taustalla olevia valintoja ja arvopohjaa, vaikka vastuulliseksi ja aktiiviseksi yhteiskunnalliseksi toimijaksi kasvaminen vaatii valintojen kyseenalaistamista ja muutosten tekemistä eettisen pohdinnan kautta (Hodson, 2011; Levinson, 2010; Sjöström, Frerichs, Zuin \& Eilks, 2017). Kestävyyskasvatuksessa ei riitä, että koulussa opitaan tieteen sisältötietoa (visio I) tai sen käyttämistä vastaantulevissa tilanteissa (visio II), vaan luonnontiedekasvatuksen pitää myös suoraan tukea arvopohjaista muutosta sekä yksilöissä että yhteiskunnassa. 
Tällainen kriittinen lähestymistapa luonnontieteelliseen lukutaitoon, luonnontiedekasvatuksen visio III (Sjöström ym., 2017), sisältää ajatuksen oppimisen transformatiivisuudesta ja transgressiivisyydestä (ks. LotzSisitka ym., 2015).

Tieteellisen lukutaidon visioon III liittyykin myös kestävän kehityksen kasvatukselle tyypillinen ajatus siitä, että opetuksen on rohkaistava ja mahdollistettava kansalaisaktivismia. Tavoitteena silloin on kasvattaa nuoria, jotka ovat valmiita ja halukkaita toimintaan kestävyyskriisien ja muiden yhteiskunnallisten ongelmien lieventämiseksi tai ratkaisemiseksi (Bencze, Sperling \& Carter, 2012; Hodson, 2011; Levinson, 2010). Demokratiakasvatuksessa, ympäristökasvatuksessa ja kestävyyskasvatuksessa käytettyä toimintakompetenssi (action competence) -lähestymistapaa (Mogensen \& Schnack, 2010) on viime aikoina alettu entistä useammin soveltaa myös luonnontiedekasvatuksessa (ks. Branchetti ym., 2018; Jegstad \& Sinnes, 2015; Sjöström ym., 2017). Sekä toimintakompetenssissa että niihin usein liitetyissä kestävyyskompetensseissa (sustainability competences, myös "sustain'abilities", ks. Wiek ym., 2011) keskeistä on oppilaiden tietoisuus omista päätöksistään ja toimistaan. Niinpä nämä kompetenssit kytkeytyvät läheisesti toimijuuteen, joka tyypillisesti ymmärretään kyvyksi tarkoitukselliseen toimintaan (esim. Emirbayer \& Mische, 1998; Lipponen \& Kumpulainen, 2011). Seuraavassa luvussa käsitellään tarkemmin toimijuutta luonnontiedeopetuksen yhteydessä.

Nämä painotukset ovat nopeasti voimistuneet viime aikoina luonnontiedekasvatuksen kentällä myös reaktiona Greta Thunbergin käynnistämään nuorten ilmastoliikkeeseen sekä vuonna 2020 alkaneeseen koronaviruspandemiaan (Erduran, 2020). Kestävään kehitykseen, toimintaan ja toimijuuteen liittyvät teemat olivat ennennäkemättömän paljon esillä viimeisimmässä ESERA 2019 -konferenssissa (European Science Education Research Association), ja maaliskuussa 2020 Science \& Education -lehti pyysi alan tutkijoita pohtimaan pandemian vaikutusta luonnontiedeopetuksen uudelleensuuntauksiin (Erduran, 2020). Tutkimusyhteisön laajempi vastaus tähän kutsuun on vielä tätä kirjoitettaessa näkemättä, mutta tässä artikkelissa argumentoidaan, että keskeinen haaste transformatiivisen toimijuuden tukemisessa liittyy lasten ja nuorten tulevaisuusajatteluun. Seuraavissa luvuissa pohditaan tulevaisuusajattelun roolia ensin kestävyyskasvatuksessa ja sitten erityisesti luonnontieteen didaktiikassa.

\section{Tulevaisuusajattelun ja toimijuuden tukeminen osana kestävyyskasvatusta}

\section{Tulevaisuudentutkimuksen työkalut kestävyyskasvatuksessa}

Globaalit kestävyyskriisit sekä nopea yhteiskunnallinen ja teknologinen kehitys pakottavat katsomaan eteenpäin, mutta samalla ne vaikeuttavat tulevan ennakointia (Masini, 1993; Rickards, Ison, Fünfgeld \& Wiseman, 2014). On tärkeää, että tulevaisuus nähtäisiin toiveikkaana ja siihen koettaisiin voitavan vaikuttaa myös epävarmuuden edessä (Lombardo, 2016; Ojala, 2012; Ono, 2003). Epävarmat ajat vaativat joustavuutta ja kykyä kohdata millainen tulevaisuus tahansa (Masini, 1993; Rickards ym., 2014). 
Tulevaisuudentutkimus on monitieteellinen tutkimusala, joka tutkii mahdollisia kehityskulkuja ja kehittää työkaluja tulevaisuusajatteluun (Ahvenharju, Minkkinen \& Lalot, 2018; Bell, 1997; Rubin, 2013). Tulevaisuudentutkimus pyrkii ymmärtämään kompleksisia yhteiskunnallisia ilmiöitä holistisesti ja systeemisesti soveltaen sekä sosiologian, filosofian, historiantutkimuksen, yhteiskuntatieteiden, psykologian, taloustieteen että luonnontieteidenkin lähestymistapoja, malleja ja menetelmiä. Perusajatuksena on tulevaisuuden koostuminen erilaisista vaihtoehdoista: tulevaisuudentutkijat tyypillisesti puhuvat tulevaisuuksista monikossa. Tulevaisuusskenaarioita voidaan rakentaa eri lähtökohdista: millainen tulevaisuus voisi olla (mahdolliset tulevaisuudet), millainen sen haluttaisiin olevan (toivotut tulevaisuudet) ja millainen se luultavasti on (todennäköiset tulevaisuudet) (ks. esim. Hicks \& Holden, 1995; Voros, 2003). Tulevaisuudentutkijoiden mukaan vaihtoehtoisten skenaarioiden ajattelu kehittää tulevaisuustietoisuutta (Ahvenharju, Minkkinen \& Lalot, 2018; Lombardo, 2016) ja valmistaa siihen tulevaisuuteen, josta tulee nykyisyys (Bishop ym., 2007). Ymmärtämällä tulevaisuuksien moninaisuus on mahdollista nähdä vaihtoehtoisia ratkaisuja ja omia vaikutusmahdollisuuksia (Carabelli \& Lyon, 2016; Ono, 2003).

Tulevaisuudentutkimuksen lähtökohdissa ja menetelmissä on paljon yhtymäkohtia sekä Unescon (2017) että OECD:n (2018) asettamiin kestävyyskasvatuksen tavoitteisiin. Kestävän kehityksen kasvatukseen kuuluvaan ennakoinnin taitoon yhdistetään moninaisten tulevaisuuksien kuvittelu ja niiden suhteuttaminen omiin toiveisiin (Unesco, 2017, s. 10). Myös OECD:n Future of Education and Skills -hankkeessa kehitetty oppimisen viitekehys korostaa tulevaisuusajattelun merkitystä kestävässä kehityksessä: vastuullinen toiminta edellyttää ennakointia (anticipation) ja reflektiota (reflection) (OECD, 2018). Onkin hyvin perusteltua hyödyntää tulevaisuudentutkimuksen kehittämiä menetelmiä kestävään kehitykseen tähtäävässä pedagogiikassa.

Tulevaisuudentutkimuksen menetelmät voivat laajentaa yksilöiden ja yhteisöjen tulevaisuusajattelua ja edesauttaa muutosta (Sharpe ym., 2016). Vaikka tulevaisuutta ei voi ennustaa, voimme muodostaa erilaisia mielikuvia tulevista tapahtumista, joista syntyy joukko vaihtoehtoisia tulevaisuuksia (Bishop, Hines \& Collins, 2007). Kun tulevaisuudelta näin poistuu ennalta määritellyn leima, voidaan ymmärtää tekojen ja valintojen vaikutusta mahdollisiin, todennäköisiin ja toivottuihin tulevaisuuksiin. Arvot yhdistyvät voimakkaasti siihen, mitä kukin pitää toivottuna, ja ne ovat väistämättä yhteydessä tulevaisuuteen ja siitä käytävään keskusteluun. Tulevaisuuskuvat eli ajatukset tulevaisuudesta ilmentävät yksilön suhdetta tulevaisuuteen ja ohjaavat ja motivoivat nykyisyyden valintoja ja toimintaa (Ahvenharju, Minkkinen \& Lalot, 2018; Carabelli \& Lyon, 2016; Lombardo, 2016; Rubin, 2013). Tulevaisuuskuvien vaikutus on vahva: ihminen pyrkii päätöksillään joko tuomaan esiin toivomansa tulevaisuuden tai estämään ei-toivomansa (tai pelkäämänsä) tulevaisuuden tapahtumia (Bell, 1997; Rubin, 2013). Tutkimusten mukaan myönteiset tulevaisuuskuvat ja toivon näkökulma rohkaisevat näkemään mahdollisuuksia ja vaihtoehtoja (Lombardo \& Cornish, 2010), myös ympäristöasioissa ja ilmastonmuutoksen torjunnassa (Ojala, 2012; Tolppanen ym., 2017). Kielteiset tulevaisuuskuvat rajoittavat mahdollisten tulevaisuuksien 
näkemistä, mikä puolestaan saattaa johtaa siihen, että tulevaisuus "kolonialisoituu" (Masini, 1993, s. 8) ja se rakennetaan jonkun muun antamana (Hutchinson, 1996).

\section{Toimijuus kestävyyskasvatuksessa}

Vaikka myönteiset tulevaisuuskuvat ovat merkityksellisiä yksilön hyvinvoinnissa ja käyttäytymisessä, ei pelkillä haaveilla saada aikaan toivottua tulevaisuutta. Tarvitaan myös tarkoituksenmukaista toimintaa, jotta toivotusta tulevaisuudesta voi tulla toteutunut tulevaisuus. Tarkoituksenmukaista toimintaa eivät määritä vain yksilön tavoitteet, vaan myös kyvyt toimia vuorovaikutuksessa yhteiskunnan ja ympäristön rakenteiden kanssa (Emirbayer \& Mische, 1998). Toimijuus on käsitteenä hyvin ajankohtainen ja sitä liitetään moniin asiayhteyksiin puhuttaessa niin aktiivisen kansalaisen rooleista (Hodson, 2003, 2011) kuin yksilön kyvyistä (Bandura, 1989).

Toimijuuden tukeminen on otettu yleiseksi kasvatustavoitteeksi paitsi kansainvälisesti (OECD, 2018; Unesco, 2017) myös Suomessa (Opetushallitus, 2014). Vuoden 2004 perusopetuksen opetussuunnitelman perusteissa (Opetushallitus, 2004) sanaa toimijuus ei vielä käytetä ollenkaan. Oppilas nähdään aktiivisena toimijana joihinkin oppiaineisiin liitetyissä tavoitteissa, mutta maininnat niissäkin jäävät vielä vähäisiksi. Sen sijaan tuoreimmissa opetussuunnitelmien perusteissa (Opetushallitus, 2014) toimijuus ja toimija -käsitteet ovat keskeisissä rooleissa. Toimijuuden tukemisella pyritään aktiiviseen kansalaisuuteen sekä demokratian ylläpitoon (Opetushallitus, 2014, s. 17), ja opetussuunnitelmien perusteiden kestävän kehityksen tavoitteissa nähdään selvästi visio III -tyyppinen (vrt. edellinen luku) näkökulma toimijuuteen. Suomen nykyiset perusopetuksen opetussuunnitelmien perusteet painottavatkin toimijuutta tavalla, joka on tyypillistä kestävyyskasvatuksessa (Unesco, 2017) ja ilmastokasvatuksessa (Tolppanen ym., 2017).

Tutkimuskirjallisuudessa esitetyille toimijuus-käsitteen määritelmille yhteistä on halukkuus, kyvyt ja mahdollisuudet merkitykselliseen toimintaan, jolla pyritään vaikuttamaan niin omaan kuin yhteiseen parempaan tulevaisuuteen. Hoffman ja Rainio (2007) kuvaavat toimijuutta paitsi yksilön myös yhteisön mahdollisuudeksi ja haluksi vaikuttamiseen ja muutokseen. Toimijuuteen liittyy toimijan aktiivinen ja autonominen rooli omassa elämässään ja ratkaisuissaan (Lipponen \& Kumpulainen, 2011). Jatkuva oppiminen sekä aktiivinen ja vastuullinen kansalaisuus ovat myös kestävyyskasvatuksen tavoitteita muuttuvan ja epävarman tulevaisuuden kohtaamiseen. Toimijuus liitetään usein välttämättömäksi osaksi sosiaalisia rakenteita: rakenteet muokkaavat toimintaa ja toiminta rakenteita (Emirbayer \& Mische, 1998). Vaikka toimijuudessa keskeisenä on yksilön toimintakyky, joka mahdollistaa rakenteisiin vaikuttamisen, ei toimijuus kuitenkaan rajaudu pelkästään yksilön ominaisuudeksi, vaan se on sosiaalisesti jaettua ja sidoksissa toiminnan kontekstiin (Biesta \& Tedder, 2007; Hoffman \& Rainio, 2007; Lipponen \& Kumpulainen, 2011).

Edellä esitetyt toimijuusmääritelmät rakentuvat pitkälti Emirbayerin ja Mischen (1998) klassisen määritelmän varaan. He kuvasivat toimijuutta kolmen eri aikaulottuvuuden muodostamana "kolmisointuna". Nämä ulottuvuudet ovat iteratiivinen (orientoitunut menneisyyteen), projektiivinen 
(orientoitunut tulevaisuuteen) ja käytännöllis-evaluatiivinen (orientoitunut nykyhetkeen). Emirbayerin ja Mischen (1998) avainargumentti on, että eri hetkinä ja eri tilanteissa ihmiset painottavat toimijuuden kolmea aikaulottuvuutta eri tavoin eli omaksuvat erilaisia toimijuusorientaatioita.

\section{Tulevaisuusajattelun ja toimijuuden yhteys}

Emirbayerin ja Mischen (1998) toimijuusmääritelmä tarjoaa hyviä mahdollisuuksia ymmärtää edellä esitellyn tulevaisuusajattelun merkitystä toimijuuden muodostumisessa. Ihmisen eri hetkinä ja tilanteissa osoittama kyky toimintaan, kuvittelemiseen ja muutosten aikaansaamiseen rakenteissa riippuu siitä, millaisena hän kokee suhteensa menneeseen, nykyhetkeen ja tulevaisuuteen. Iteratiivinen menneeseen orientoituminen tuottaa uusintavaa, reproduktiivista toimijuutta, kun taas projektiivinen tulevaisuuteen orientoituminen tuottaa uudistavaa, transformatiivista toimijuutta (Emirbayer \& Mische, 1998, ss. 973, 1004, 1008). Tulevaisuudentutkimuksessa käytetyt ajattelun tavat - erityisesti vaihtoehtoisten tulevaisuuksien kuvittelu sekä arvoista, unelmista ja tavoitteista lähtevä toivottavien tulevaisuuksien kuvittelu - tukevat erityisesti toimijuuden projektiivista ulottuvuutta (Emirbayer \& Mische, 1998). Tälle toimijuusulottuvuudelle tyypillistä on kyky hetkellisesti irrottautua ajattelua rajoittavista oletuksista, skeemoista, tavoista ja perinteistä (imaginative distancing, ks. Emirbayer \& Mische, 1998; Mead, 1932). Juuri tähän tarkoitukseen tulevaisuudentutkimuksessa on kehitetty menetelmiä kuten visiointi ja backcasting -menetelmä (Bishop ym., 2007; Robinson, 1990). Voidaankin argumentoida, että tulevaisuusajattelun harjoittelu voi tukea projektiivisen ulottuvuuden kautta juuri transformatiivista toimijuutta.

Tulevaisuusajattelu näyttäytyykin keskeisenä sellaisessa muutoksen tekemiseen tähtäävässä kestävyyskasvatuksessa, jota edellä käsiteltiin luonnontiedeopetuksen tavoitteena. Kasvatustavoitteiden peräänkuuluttama transformatiivinen toiminta edellyttää transformatiivista toimijuusorientaatiota. Transformatiivinen toimija on tulevaisuuden muutosagentti (OECD, 2018, s. 4), joka näkee vaihtoehtoisia ja toivottavia tulevaisuuksia sekä omia vaikutusmahdollisuuksiaan niihin tulevaisuuksiin pääsemiseksi. Toimijuus ja tulevaisuuskuvat kietoutuvat tiiviisti toisiinsa. Käsitykset vaikutusmahdollisuuksista ja toimijuudesta ovat tärkeä tekijä yksilön tulevaisuustietoisuudessa (Ahvenharju, Minkkinen \& Lalot, 2018; Sharpe ym., 2016). Tulevaisuus on läsnä nykyisyydessä aikomusten, tavoitteiden, haaveiden, toiveiden ja pelkojen kautta, jotka näin vaikuttavat ihmisen toimintaan, joka puolestaan vaikuttaa toteutuviin tulevaisuuksiin (Carabelli \& Lyon, 2016; Cuzzocrea \& Mandich, 2016; Rubin, 2013).

Mukaillen Emirbayerin ja Mischen (1998) ajatusta toimijuuden "kolmisoinnusta" on kuitenkin huomautettava, että vaikuttava toiminta vaatii yhden toimijuusulottuvuuden sijasta kaikkien kolmen vuorovaikutuksen. Siis myös menneisyyteen orientoituneella iteratiivisella ajattelulla, kuten käsityksillä aiemmin tapahtuneesta ja omasta pystyvyydestä (vrt. myös Bandura, 1989), on tärkeä paikkansa rakenteita uudistavassa toimijuudessa. Yhtä lailla on selvää, että toimijuus on kaikella todennäköisyydellä hyvin heikkoa siinä äärimmäisessä tilanteessa, että vain yksi toimijuusulottuvuus on aktiivinen. Tällainen tilanne olisi sosiologi Hartmut Rosan (2013) mukaan yhteiskunnan kiihtyvästä muutoksesta seuraava 
tilannekohtainen identiteetti (situational identity) ja "kuumeinen seisahdus" (frenetic standstill). Siinä tilassa ajattelu ja toiminta keskittyvät kokonaan pelkästään nykyhetkeen; toimijuus ei perustu kuvaan menneisyydestä eikä suuntaudu näkymään tulevaisuudesta. Rosan (2013) lisäksi muutkin filosofit ja sosiologit ovat nostaneet tämän tyyppisiä huolia nuorten tulevaisuusajattelusta - ja varsinkin sen puutteesta - ja sen myötä toimijuudesta, kun nuoret kohtaavat nyky-yhteiskuntien nopean muutoksen ja kompleksisuuden, globaalit kriisit ja tulevaisuuden epävarmuuden (Giddens, 1991; Leccardi, 2012).

Vuonna 2020 maailmaa mullistava koronaviruspandemia saattaa kiihdyttää tällaista ihmisten näkökentän typistymistä. On esitetty huolia siitä, että viruksen leviämiseksi tehtävällä sosiaalisella eristäytymisellä voi olla pitkäkestoisiakin vaikutuksia ihmisten näköaloihin: pandemian jälkeenkin saatetaan keskittyä entistä enemmän omaan ja läheisten hyvinvointiin nykyhetkessä. Mediassa on ennakoitu, että tällainen kehitys voi mahdollistaa myös populismin uutta aaltoa (ks. esim. Sirén, 2020; Virtanen, 2020). Voidaankin argumentoida, että nämä uhat yhdessä edelleen eskaloituvien globaalien kestävyysongelmien kanssa vaativat koulutusjärjestelmiltä laajemman tulevaisuusajattelun tietoista harjoittelua.

\section{Tulevaisuusajattelu luonnontiedekasvatuksessa}

\section{Perusteluja luonnontiedeopetuksen tulevaisuusorientaatiolle}

Edellisessä luvussa kuvatun kaltainen tulevaisuusajattelun ja toimijuuden kehittäminen istuu erityisen hyvin osaksi luonnontiedekasvatusta. Kuten edellä esitettiin, luonnontiedeopetuksen tavoitteet ovat maailmanlaajuisesti siirtyneet kohti kestävyyskasvatusta ja erityisesti muutoksen tekemistä ja luonnontieteellisen lukutaidon visiota III (Hodson, 2003, 2011; Sjöström ym., 2017). Tulevaisuuden eksplisiittinen käsittely opetuksessa tarjoaa kestävyyskasvatuksessa olennaisen aikaperspektiivin, joka ylittää tämänhetkiset välittömät tarpeet. Tämä on tärkeää, koska tutkimusten mukaan nuorten myönteinen tulevaisuusajattelu ja vaikutusmahdollisuuksien kokeminen on usein rajoittunutta lähitulevaisuuteen ja paikallistasolle (Cook, 2016; Heikkilä, Nevala, Ahokas, Hyttinen \& Ollila, 2017). Niinpä tulevaisuusulottuvuuden vahvistaminen auttaa tukemaan oppilaiden altruistisia dispositioita ottamalla globaalisti huomioon tulevien sukupolvien tarpeet (Lloyd \& Wallace, 2004), mikä on kestävän kehityksen kasvatuksen ytimessä.

Yhteiskunnallisten tulevaisuuksien käsittely luonnontiedeopetuksessa on perusteltua siksikin, että valtaosa nuorten deterministisistä ja dystooppisista peloista liittyy tieteeseen ja teknologiaan (Carter \& Smith, 2003; Tasquier, Branchetti \& Levrini, 2019). Itsestäänselviltä tuntuvien tieteellis-teknologisten skenaarioiden problematisointi auttaa näkemään vaihtoehtoja ja vaikutusmahdollisuuksia. Toisaalta, hieman paradoksaalisesti, tieteen ja teknologian on havaittu liittyvän monilla tavoilla myös nuorten toiveisiin ja unelmiin kestävämmästä tulevaisuudesta (Cook, 2016; Lloyd \& Wallace, 2004). Tulevaisuusorientoitunut opetus voikin auttaa oppilaita arvioimaan tieteen ja teknologian sekä myönteisiä että kielteisiä vaikutuksia yhteiskuntaan ja ympäristöön. Lisäksi on havaittu, 
että odotukset teknologiasta ja tulevaisuuden epävarmuudesta vaihtelevat hyvin paljon sen mukaan, kuinka paljon yksilöt kokevat vaikutusmahdollisuuksia teknologiseen kehitykseen (Borup, Brown, Konrad \& Van Lente, 2006). Tämän perusteella luonnontiedeopetus tarjoaakin suoria mahdollisuuksia edellisessä luvussa käsitellyn toimijuuden vahvistamiseen.

Tulevaisuusajattelun keinoja hyödyntämällä voidaan siis pystyä monipuolisesti lisäämään oppilaiden kokemaa yksilöllistä ja yhteiskunnallista relevanssia luonnontiedeopetukseen, jonka varsinkin vision I mukaisena on laajalti todettu tuntuvan merkityksettömältä kompleksisissa ongelmissa ja vieraannuttavan oppilaita luonnontieteestä (Carter \& Smith, 2003; Stuckey ym., 2013). Tutkittaessa oppilaiden kiinnostusta luonnontiedeaineisiin on havaittu, että juuri tulevaisuusfokus herättää kiinnostusta yhteiskunnallisia kysymyksiä hyödyntävässä SSI-opetuksessa (Osborne \& Collins, 2000). Relevanssin lisäksi tulevaisuusperspektiivin voidaan argumentoida lisäävän myös luonnontiedeopetuksen autenttisuutta (Kapon, Laherto \& Levrini, 2018). Tulevaisuus on sisäänrakennettuna tieteen luonteeseen: mallintaminen ja ennusteiden tekeminen ovat oleellisia luonnontieteen epistemologiassa (Branchetti ym., 2018; Levrini, Tasquier, Branchetti \& Barelli, 2019), ja ymmärrys esimerkiksi lineaaristen kausaalimallien, probabilististen mallien ja kompleksisten systeemien mallintamisen eroista on tärkeää puhuttaessa tulevaisuusennusteista. Lisäksi luovuus ja mielikuvitus ovat keskeisessä roolissa sekä tieteessä että sen oppimisessa (Hilppö, Rajala, Zittoun, Kumpulainen \& Lipponen, 2017).

Tulevaisuusnäkökulmien tuominen luonnontiedekasvatuksen keskiöön on siis monella tavalla perusteltua. Tästä huolimatta opetussuunnitelmissa tyypilliset luonnontiedeopetuksen lähestymistavat joko eivät eksplisiittisesti käsittele ajallista ulottuvuutta tai ovat tieteenhistoriaan orientoituneita (Stuckey ym., 2013). Tulevaisuuden käsittelyn vähäisyyden, pinnallisuuden ja yksioikoisuuden on väitetty olevan tyypillistä muullekin kasvatukselle, jossa usein varotaan lisäämästä oppilaiden huolta ja levottomuutta ja sen takia päädytään ohittamaan tulevaisuuden epävarmuus ja vaihtoehtoisuus (Hutchinson, 1996, Levrini ym., 2020). Tätä kasvatuksen lisäksi muitakin yhteiskunnan aloja koskevaa taipumusta on käsitelty sosiologiassa "tulevaisuuden poistamisena" (de-futurizing, ks. Bergmann, 1992). Lähestymistavan vaaroista on varoiteltu (ks. esim. Hutchinson, 1996, s. 48): jos itsestään selviä tulevaisuudenajattelutapoja ei kyseenalaisteta, uhkaa tulevaisuushorisonttien sulkeutuminen ja ulkoapäin tehtyjä valintoja luullaan välttämättömyyksiksi. Tällä tavalla orientoitunut opetus on vähintäänkin tehotonta - ellei haitallista - oppilaiden näkemyksille tulevaisuudestaan ja mahdollisista tieteen ja teknologian rooleista siinä. Tässä mielessä tulevaisuuden sisällyttämistä luonnontiedekasvatukseen ovat pohtineet esimerkiksi Carter ja Smith (2003) sekä Lloyd ja Wallace (2004).

\section{Lähestymistapoja tulevaisuusorientoituneeseen luonnontiede- opetukseen}

Yhteiskunnallisia kysymyksiä luonnontiedeopetukseen tuova SSIlähestymistapa (ks. Zeidler ym., 2005) tarjoaa luontevan pedagogisen viitekehyksen sekä kestävyyskasvatukselle että tulevaisuusajattelulle. Luonnontieteitä ja ihmistieteitä yhdistävissä kompleksisissa ongelmissa oppilaita kiinnostaa juuri tulevaisuusaspekti (Osborne \& Collins, 2000; 
Levrini ym., 2016). Sekä Hodson (2011) että Sjöström ja muut (2017) ovat kuitenkin kritisoineet, että tavanomaisessa SSI-opetuksessa ajattelu rajoittuu lähitulevaisuuteen, ja tulevaisuuksien moninaisuus, oletusten kyseenalaistaminen ja arvopohdinnat voivat jäädä pintapuoliselle huomiolle. Samoin käy usein myös tyypillisissä lähestymistavoissa luonnontiedeopetuksen relevanssin parantamiseksi (vrt. Kapon, Laherto \& Levrini, 2018), vaikka didaktisessa tutkimuksessa ja opetussuunnitelmatyössä paljon käytetty relevanssimalli (Stuckey ym., 2013) näennäisesti sisältääkin tulevaisuusulottuvuuden. Viime vuosikymmenen aikana luonnontiedekasvatuksen tutkijat ja kehittäjät ovatkin esittäneet vaatimuksia tulevaisuusaspektien eksplisiittisestä sisällyttämisestä opetukseen, jotta se voisi laajentaa oppilaiden näköaloja ja mahdollisuuksia toimijuuteen ja muutokseen epävarmuuden leimaamassa maailmassa (Branchetti ym., 2018; Buntting \& Jones, 2015; Jones ym., 2012; Levrini ym., 2019; Paige \& Lloyd, 2016; Tasquier, Branchetti \& Levrini, 2019).

Tulevaisuudentutkimuksen keinoja hyödyntävää tulevaisuusajattelun kehittämistä on kuitenkin ollut vasta muutamissa 2000- ja 2010luvun hankkeissa. Jones ja muut (2012) ottivat SSI-lähestymistavan perustaksi ehdottamalleen käsitteelliselle viitekehykselle, jonka tarkoitus on tukea tulevaisuusajattelua vahvistavan opetuksen suunnittelua (ks. myös Buntting \& Jones, 2015). Viitekehyksessä sisällytetään opetukseen viisi elementtiä, jotka ovat tyypillisiä tulevaisuudentutkimuksessa tehtävälle skenaarionrakentamiselle: nykytilanteen ymmärtäminen, suuntausten ja trendien tunnistaminen, muutosten syiden analysointi, mahdollisten ja todennäköisten tulevaisuuksien kehittäminen, ja lopulta toivottavien tulevaisuuksien valitseminen (Jones ym., 2012). Myös Lloyd kollegoineen (Lloyd \& Wallace, 2004; Paige \& Lloyd, 2016) ovat kehittäneet tulevaisuusorientoitunutta luonnontiedeopetuksen lähestymistapaa, jossa tarjotaan oppilaille laveampia perspektiivejä varsinkin tunnistamalla ja kuvittelemalla vaihtoehtoisia, yhteiskunnallisesti ja ympäristöllisesti kestävämpiä tulevaisuuksia. Näiden kanssa saman tyyppistä lähestymistapaa kehitettiin myös Euroopan unionin rahoittamassa I SEE -projektissa (Branchetti ym., 2018), jossa kehitettyjä opetusmenetelmiä ja niiden tuloksia esitellään lyhyesti seuraavassa luvussa.

\section{Kokemuksia I SEE -hankkeesta}

Tässä luvussa esitellään lyhyesti I SEE -projektissa (https://iseeproject.eu) kehitettyä tulevaisuusorientoitunutta luonnontiedeopetusta. Tavoitteena on konkretisoida artikkelissa esitettyjä ajatuksia tulevaisuusajattelun opettamisesta osana kestävän kehityksen luonnontiedekasvatusta. Opetusmenetelmien esittelyn jälkeen nostetaan artikkelin teemojen kannalta relevantteja poimintoja menetelmiä kokeilleiden opiskelijoiden kokemuksista, joita on kattavammin selvitetty toisaalla raportoitavilla empiirisillä tutkimuksilla (Branchetti ym., 2018; Levrini ym., 2020; Rasa, Laherto \& Palmgren, 2020; Tasquier, Levrini, Laherto, Wilson \& Palmgren, 2018). Viitattavien tutkimusten metodologiaa referoidaan vain pääpiirteissään, koska käsittelyn tarkoitus on ainoastaan kommentoida artikkelin teoreettisten ehdotusten käytännöllistä toteutettavuutta ja mahdollisia hyötyjä 
tulevaisuusajattelun harjoittelussa. Tässä lyhyesti esiteltävä opetusmateriaali (Palmgren, Laherto, Tuominen \& Puranen, 2019) on kokonaisuudessaan saatavilla hankkeen verkkosivuilta https://iseeproject.eu.

Euroopan unionin Erasmus+ -ohjelman vuosina 2016-2019 rahoittama projekti I SEE (Inclusive STEM Education to Enhance the capacity to aspire and imagine future careers) pyrki vastaamaan luvussa 3 käsiteltyihin huoliin siitä, että ilmastokriisistä sekä kiihtyvästä yhteiskunnallisesta muutoksesta johtuen monilla nuorilla on vaikeuksia projisoida itsensä tulevaisuuteen ja nähdä itsensä aktiivisina ja vastuullisina yksilöinä, kansalaisina ja ammattilaisina (Branchetti ym., 2018). Hankkeen pedagogiassa sovellettiin tässä artikkelissa käsiteltyjä tulevaisuudentutkimuksen menetelmiä ja ajattelutapoja sekä kestävyyskasvatuksen action competence -lähestymistapaa. I SEE -partnerit Islannissa, Italiassa ja Suomessa kehittivät lukiolaisten opintojaksoja, joissa tulevaisuus- ja kestävyysajattelu yhdistettiin ajankohtaisiin, luonnontieteisiin liittyviin yhteiskunnallisiin kysymyksiin: opintojaksojen teemoina olivat ilmastonmuutos, tekoäly, kvanttitietokoneet ja hiilidioksidin talteenotto.

Suomessa kehitettiin "Kvanttitietokoneet ja tietotekniikan tulevaisuus" -niminen opintojakso (Palmgren ym., 2019), joka sisälsi 20 tuntia lähiopetusta sekä koti- ja ryhmätyötehtäviä. Opintojakson tavoitteena oli kehittää lukiolaisten tulevaisuusajattelun taitoja, mielikuvitusta ja yhteiskunnallista toimijuutta. Opittua sovellettiin pohdittaessa tietotekniikan roolia tulevaisuuden haasteissa, mutta opittavat taidot ovat oleellisesti transversaaleja ja ulottuvat muuhunkin henkilökohtaiseen, yhteiskunnalliseen ja globaaliin tulevaisuusajatteluun. Opintojakson alussa syvennettiin ymmärrystä tietotekniikan historiallisesta kehityksestä ja sen yhteydestä yhteiskunnalliseen kehitykseen sekä tarkasteltiin teknologisen tulevaisuuden ennakoimisen kompleksisuutta. Opiskelemalla eri kantalukujärjestelmiä, loogisia operaatioita, algoritmeja ja tietokoneen komponentteja pohjustettiin siirtymää nykyisestä laskentaparadigmasta uuteen: bittien korvaamista kubiteilla. Kvanttiominaisuuksien ja kvanttialgoritmien kautta päästiin pohtimaan kvanttitietokoneiden ylivoimaista laskentatehoa sekä niiden tarjoamia tulevaisuuden mahdollisuuksia. Lisäksi ammennettiin hedelmällisestä synergiasta, joka on kvanttimekaniikan ja tulevaisuudentutkimuksen välillä: molemmilla aloilla opiskelijoiden on irtauduttava totutuista ajattelutavoista, kyseenalaistettava oletuksia ja tarkasteltava todennäköisyyksiä ja kausaliteetteja uudella tavalla.

Opintojakson alussa opiskelijat valitsivat heitä kiinnostavan tai huolestuttavan yhteiskunnallisen ongelman, joista he sitten 3-5 opiskelijan pienryhmissä työstivät omia "tulevaisuusprojektejaan". Tyypillisesti opiskelijat valitsivat ympäristöllisiä, sosiaalisia tai taloudellisia kestävyysongelmia, hyvin relevantteja kestävyyskasvatuksen teemoja. Näitä ongelmia ja niiden mahdollisia ratkaisuja työstettiin ohjatuissa aktiviteeteissa, joissa harjoiteltiin luovaa ajattelua, ongelman määrittelyä ja kartoittamista, systeemiajattelua, vaikutusmahdollisuuksien löytämistä ja skenaarioiden laatimista. Aktiviteetit pohjautuivat tulevaisuudentutkimuksen lähestymistapoihin, joissa ymmärretään tulevaisuuksien moninaisuus, irrottaudutaan deterministisestä ajattelusta, tunnistetaan ja kyseenalaistetaan oletuksia ja opitaan, että pienistä muutoksista voi ajan mittaan seurata suuria systeemitason muutoksia. Opiskelijat kehittivät valitsemilleen 
ongelmille todennäköisiä, vaihtoehtoisia ja toivottavia tulevaisuusskenaarioita soveltaen tulevaisuudentutkimuksen (ks. esim. Bishop ym., 2007; Hicks \& Holden, 1995; Voros, 2003) tarjoamia kolmea perustavanlaatuisesti erilaista tulevaisuusajattelun tapaa: 1) nykyisten suuntausten ja trendien ekstrapolointia, 2) oletusten kyseenalaistamista ja luovaa vaihtoehtoajattelua, ja 3) omista arvoista ja tavoitteista lähtevää visiointia. Opintojakson lopuksi pienryhmät esittelivät toisilleen ajattelutavoista jälkimmäiseen eli toivottavaan skenaarioonsa pohjaamansa "tulevaisuusprojektin": osittain tietotekniikkaan liittyvän mutta systeemitason tarkastelua vaativan ratkaisun yhteiskunnalliseen ongelmaan. Esitykset rakennettiin soveltamalla tulevaisuudentutkimuksen backcasting-menetelmää (Bishop ym., 2007; Robinson, 1990): ensin kuviteltiin tulevaisuus, jossa ongelma on ratkaistu, sitten tarkasteltiin miten muiden systeemien osien on täytynyt muuttua siinä tulevaisuudessa, ja lopuksi ajateltiin kehityspolku ajassa taaksepäin tulevaisuudesta nykyhetkeen. Opintojakson päätösseminaarissa, jonka leikittiin tapahtuvan vuonna 2040, opiskelijat kertoivat imperfektissä "menestystarinansa" - miten kaikki tapahtui, millaiset roolit heillä kullakin oli ongelman ratkaisussa, keiden apua he tarvitsivat ja minkälaisia vaiheita ja vastoinkäymisiä matkan varrella oli.

"Kvanttitietokoneet ja tietotekniikan tulevaisuus" -opintojakso toteutettiin huhtikuussa 2018 Helsingissä, helmikuussa 2019 Italian Bolognassa, ja huhtikuussa 2019 uudelleen Helsingissä. Helsingissä opintojaksoa mainostettiin pääkaupunkiseudun luonnontiedepainotteisissa lukioissa, jotka myös hyväksilukivat suorituksen valinnaisena lukiofysiikan kurssina. Kahdelle Helsingissä järjestelylle kurssille osallistui yhteensä 50 opiskelijaa (16-19-vuotiaita). Hakijoita oli jonkin verran enemmänkin, ja valintaperusteena käytettiin ilmoittautumisjärjestystä.

Helsingissä opintojakson osallistujien tulevaisuusajattelua ja kurssin vaikutusta siihen on tutkittu analysoimalla kolmenlaista dataa (Rasa, Laherto \& Palmgren, 2020; vrt. Branchetti ym., 2018; Levrini ym., 2020): 1) ennakkotehtävänä kirjoitettuja esseitä otsikolla "Tyypillinen kesäpäivä vuonna 2040", 2) yksilöhaastatteluja noin viikko opintojakson jälkeen, ja 3) pienryhmien loppuesitelmiä eli "tulevaisuusprojekteja". Näin projektissa voitiin analysoida opiskelijoiden alustavia tapoja ajatella tulevaisuutta, heidän käsityksiään ajattelun muuttumisesta opintojakson aikana ja ajattelun ilmenemistä opiskelijoiden ryhmätöissä. Empiiristen tutkimusten metodologia ja tulokset raportoidaan toisaalla (Rasa, Laherto \& Palmgren, 2020), mutta tässä poimitaan joitain tämän artikkelin kannalta relevantteja huomioita.

Opiskelijoiden ennakkoesseissä nähtiin sekä optimistisia että pessimistisiä näkymiä globaaliin tulevaisuuteen. Uhat ja pelot liittyivät ilmastonmuutokseen, sosiaaliseen epätasa-arvoon, työttömyyteen, teknologian väärinkäyttöön, ylikansoittumiseen ja luonnonvarojen riittämättömyyteen. Opiskelijoilla oli suuria odotuksia tieteen ja teknologian tuomista ratkaisuista kestävyysongelmiin, mutta harvoin näkemystä omasta roolistaan ratkaisuissa. Haastatteluiden sisältöanalyysin perusteella opiskelijat kehittivät opintojakson aikana entistä myönteisempiä tulevaisuuskuvia, oppivat ajattelemaan monipuolisemmin erilaisia tulevaisuusskenaarioita ja löysivät uusia vaikutusmahdollisuuksia sekä omaan että globaaliin tulevaisuu- 
teen. Backcasting-metodi koettiin erityisen voimaannuttavana. Opintojakso auttoi opiskelijoita myös löytämään luonnontieteitä ja ihmistieteitä integroivia työuravaihtoehtoja - myös kuvittelemaan ammatteja, joita ei vielä ole. Haastatteluissa opiskelijat toivat esiin näköalojensa laajentumisen, kertoivat tulevaisuuden tulleen "ulottuville" ja uumoilivat käyttävänsä oppimiaan skenaario- ja systeemiajattelun tekniikoita jatkossakin. Projektitöissään opiskelijat näkivät teknologisen kehityksen tuomia mahdollisuuksia kestävyysongelmien ratkaisemisessa. Ylipäätään lukiolaiset oppivat ajattelemaan luonnontiedettä, teknologiaa, kompleksisia systeemejä ja tulevaisuuttaan tavalla, jota heidän mielestään ei koulussa opeteta.

Opiskelijoiden kokemusten perusteella näyttääkin siltä, että hankkeessa kokeillut tulevaisuusajattelua kehittävät aktiviteetit toteuttavat kestävyyskasvatuksen tavoitteita: ne voivat tarjota toiminnallista ja oppijakeskeistä pedagogiikkaa, joka tähtää vastuullisuuteen ja muutoksen aikaansaamiseen sekä oppijassa että yhteiskunnassa (vrt. Hodson, 2011; Lotz-Sisitka ym., 2015). Tässä referoidut tulokset ovat rohkaisevuudessaan myös samansuuntaisia kuin aiemmissa tulevaisuudentutkimuksen keinoja hyödyntävissä luonnontiedeopetuksen kokeiluissa. Esimerkiksi Jones ja muut (2012) raportoivat 8-18-vuotiaiden oppineen tämän tyyppisten aktiviteettien kautta muutosten, suuntausten ja syy-seuraussuhteiden tunnistamista sekä mahdollisten ja toivottavien tulevaisuuksien arvottamista. I SEE -opintojakson tulokset näyttävät tukevan tulevaisuustutkijoiden perusväitettä, jonka mukaan vaihtoehtoisten skenaarioiden ajattelu laventaa tulevaisuuskäsitystä ja valmistaa epävarmaan tulevaisuuteen (Bishop ym., 2007). Osallistujat ovat kokeneet I SEE -opintojaksot hyvin kiinnostavina ja innostavina (Branchetti ym., 2018; Levrini ym., 2020; Rasa, Laherto \& Palmgren, 2020), ja sama on huomattu aiemmissa skenaarionrakentamisaktiviteetteja luonnontiedeopetukseen yhdistäneissä kokeiluissa (Buntting \& Jones, 2015; Jones ym., 2012). Helsingissä opiskelijat kokivat tärkeänä myös sen, että tulevaisuuspohdintaa tehtiin yhdessä muiden kanssa. Ryhmätyöaktiviteetit vaikuttivatkin tukeneen yhteisöllistä osallisuutta, jota Roth ja Lee (2004) ovat ehdottaneet luonnontiedekasvatuksen tavoitteeksi ja näkökulmaksi.

On kuitenkin huomattava, että I SEE -opintojakson osallistujajoukko ei edustanut lukiolaisia laajemmin: he ilmoittautuivat vapaaehtoisesti ja olivat siten jo valmiiksi kiinnostuneita tietotekniikasta ja tulevaisuusajattelunsa kehittämisestä. Jatkossa aktiviteetteja on kokeiltava laajemmalla joukolla, ja myös aktiviteettien integroimista opetussuunnitelman kehikkoon on työstettävä yhteistyössä opettajien kanssa. I SEE -projektin lähestymistapa näyttää kuitenkin tarjoavan välineitä esiin nousseille tulevaisuusorientoituneen luonnontiedeopetuksen tarpeille. Lähestymistavassa voidaan nähdä paljon transformatiivisen kestävyyskasvatuksen ja luonnontieteellisen lukutaidon vision III (Sjöström ym., 2017) piirteitä. Opiskelijat tarkastelivat luonnontieteitä, ihmistieteitä ja teknologiaa yhdistäviä yhteiskunnallisia ongelmia kokonaisvaltaisesti ja kompleksisina systeemeinä, korostaen arvojen, valintojen ja aktiivisen osallistumisen merkitystä muutoksen aikaansaamisessa kohti kestävämpää tulevaisuutta. Opintojaksolla sovellettu ratkaisukeskeinen lähestymistapa ja tulevaisuusajattelun tekniikat näyttivät tukevan nuorten toimijuutta ja keinoja suhtautua epävarmuuteen. 


\section{Pohdinta}

Toimintamme suuntaa aina tulevaisuuteen: ratkaisumme ja päätöksemme sisältävät oletuksia tulevasta ja nykyhetken toiminnan vaikutuksista tulevaan. Nämä oletukset yleensä kuitenkin usein jäävät tiedostamattomiksi ja kyseenalaistamattomiksi. Käsitystämme ajasta ja tulevaisuudesta sumentaa myös yhteiskunnan kiihtyvä muutos (Rosa, 2013). Totuttuja tulevaisuudenajattelutapojamme on kuitenkin mahdollista ja myös tarpeellista kehittää, jotta oppisimme paremmin käsittelemään muutosta ja tulevaisuuden epävarmuutta. Keinoja ajattelun jalostamiseen on kehitetty tulevaisuudentutkimuksen alalla, ja tässä artikkelissa ehdotetaan niiden käyttöönottoa ylipäätään kestävyyskasvatuksessa ja erityisesti luonnontieteiden kouluopetuksen kontekstissa.

Luonnontieteen opetuksen, luonnontiedekasvatuksen ja tieteellisen lukutaidon tavoitteita voi tarkastella useista näkökulmista (Kapon, Laherto \& Levrini, 2018; Kokkonen \& Laherto, 2018; Roberts \& Bybee, 2014). Näkökulmasta riippuen tulevaisuusajattelu voi hyödyttää luonnontiedekasvatusta eri tavoilla: se voi esimerkiksi lisätä oppilaiden kiinnostusta ja relevanssin tunnetta luonnontiedeopetusta kohtaan (Osborne \& Collins, 2000; Stuckey ym., 2013) tai sen autenttisuutta (Kapon, Laherto \& Levrini, 2018). Tässä artikkelissa keskityttiin kuitenkin tavoitteeseen, joka on voimakkaasti korostunut 2010-luvulla sekä opetussuunnitelmissa, opetustyössä että ainedidaktisessa tutkimuksessa: luonnontiedekasvatuksella on välinearvo ja velvollisuus vastata maailmanlaajuisiin kestävyyskriiseihin. Luonnontiedeopetuksen on osaltaan tartuttava globaaliin tilanteeseen, jossa ihmisen on uudelleenmääriteltävä perustoimintoja (Tolppanen ym., 2017), muutettava paradigmoja (Laininen, 2019; Sharpe ym., 2016) ja samalla ratkaistava vanhan ajattelumallin tuomia ongelmia. Vastuulliseen muutokseen tähtäävä toimijuus onkin otettu luonnontiedeopetuksen päämääräksi sekä Suomessa (Opetushallitus, 2014) että maailmanlaajuisesti (European Commission, 2015; Hodson, 2003; Hodson, 2011; OECD, 2018; Unesco, 2017).

Kestävyyskasvatuksen tavoite liittyy luonnontieteellisen lukutaidon visioon III (Sjöström ym., 2017) eli transformatiiviseen oppimiseen, jossa opetus nähdään välineenä muutoksen aikaansaamiseen (Hodson, 2011; Levinson, 2010). Tässä artikkelissa perusteltiin, kuinka tulevaisuusajattelua harjoittava luonnontiedekasvatus voi tukea toimijuuden projektiivista ulottuvuutta (Emirbayer \& Mische, 1998) ja siten juuri uudistavan tyyppistä toimijuutta. Visiossa III luonnontieteen ja ihmistieteiden rajat myös sekoittuvat tavalla, joka on tyypillistä kestävän kehityksen kasvatukselle. Tämän tyyppinen luonnontiedeopetus kannustaa ja antaa valmiuksia tiedettä, teknologiaa, ympäristöä ja yhteiskuntaa määrittävien arvojen ja poliittisten näkemysten tunnistamiseen ja kyseenalaistamiseen - ja siten kriittiseen suhtautumiseen myös kasvatukselle asetettuja tavoitteita kohtaan. Transformatiivinen lähestymistapa siis voi kestävyystavoitteiden edistämisen lisäksi myös purkaa luonnontiedeopetuksen normatiivisuutta (Carter \& Smith, 2003).

Artikkelin otsikko perusteltiin artikkelissa paloittain. Ensin argumentoitiin, että luonnontiedekasvatuksen (science education) yleiset 
kouluopetusta koskevat tavoitteet ovat kansainvälisesti siirtyneet luonnontieteellisen lukutaidon visiosta II (Roberts, 2007; Roberts \& Bybee, 2014) kohti visiota III, transformatiivista kestävyyskasvatusta (Sjöström ym., 2017). Sitten esitettiin, että uudet kestävyyskasvatuksen tavoitteet vaativat toimijuuden ja tulevaisuusajattelun kehittämistä, ja lopuksi perusteltiin ja kuvattiin tällaisia lähestymistapoja erityisesti luonnontiedeopetuksen kontekstissa. Artikkelin otsikko tuo esiin myös artikkelin näkökulman rajauksen. Luonnontiedekasvatukseen edelleen kuuluu kestävyyskasvatuksen lisäksi paljon muitakin, sekä yksilön että yhteiskunnan kannalta tärkeitä tavoitteita (ks. esim. Kapon, Laherto \& Levrini, 2018; Kokkonen \& Laherto, 2018; Roberts \& Bybee, 2014; Stuckey ym., 2013), vaikka tämä artikkeli ei niihin keskittynytkään. Samoin holistinen kestävyyskasvatus kattaa tulevaisuusajattelun ja toimijuuden lisäksi paljon sellaisia kompetensseja ja osa-alueita, joihin tässä artikkelissa ei voitu syventyä: vähälle huomiolle jäivät kestävyyskasvatuksen tiedollinen perusta, systeeminen ajattelu, ongelmanratkaisu- ja yhteistyötaidot sekä identiteetin ja arvojen näkökulmat (Tolppanen ym., 2017; Unesco, 2017).

Artikkeliin valittu tulevaisuusajattelun näkökulma on kuitenkin juuri nyt hyvin ajankohtainen yhteiskunnallisesti - paitsi kestävyyskasvatuksen niin myös koronaviruspandemian takia. Ensinnäkin globaalin mullistuksen aiheuttanut COVID-19-pandemia on osoittanut, mitä kriiseihin varautuminen vaatii: on pystyttävä ennakoimaan myös epätodennäköiseltä tuntuvia vaihtoehtoja ja niiden monialaisia seurauksia koko kompleksiseen yhteiskuntaan. Opit eivät saisi jäädä pelkästään uusiin pandemioihin varautumiseksi, kuten nyt on pelätty tapahtuvan (ks. Niemeläinen, 2020). Uudenlaisten ja vaikeammin ennakoitavien riskien huomioon ottaminen vaatii skenaarionrakentamisen ja luovan tulevaisuusajattelun taitoja. Toiseksi, ihmisten arjen ja yhteiskunnat lamauttanut kriisi tarjoaa mahdollisuuden luoda jotain uutta. Sosiaaliantropologi Thomas Hylland Eriksen on esittänyt tilanteesta vertauksen: "Vähän kuin talosi olisi palanut, ja nyt mietit, rakennatko täysin samanlaisen vai vähän paremman" (Timonen, 2020). Pandemia voi tarjota mahdollisuuksia ajatella uudelleen globalisaatiota tai kyseenalaistaa, tarvitsemmeko kaikkea sitä, mitä meillä oli ennen. Pandemiakriisiä laajemmin tämä koskee myös ilmastonmuutoksen aiheuttaman systeemisen muutoksen tarvetta. Molemmissa tapauksissa kriisistä ulospääsy vaatii sen, että toivottavia tulevaisuuksia osataan ensin kuvitella.

Koulutusjärjestelmän tietynlainen paradoksi on, että sen koko tarkoitus on antaa valmiuksia tulevaisuuteen, mutta tulevaisuus on perustavanlaatuisesti epävarma ja sen myötä myös siinä tarvittavat valmiudet. Voidaankin argumentoida, että ne valmiudet, joita koulu voi antaa, liittyvät juuri epävarmuuden itsensä kohtaamiseen. Hyödyntämällä tulevaisuudentutkimuksen ajattelutapoja ja työkaluja voidaan pyrkiä tukemaan lasten ja nuorten kykyä suhtautua epävarmuuteen, nähdä vaihtoehtoisia tulevaisuuksia ja ottaa aktiivinen rooli toivotun tulevaisuuden luomisessa. Artikkelin ehdotukset tulevaisuusajattelun tuomisesta kestävyyskasvatukseen ja luonnontiedeopetukseen liikkuvat tässä artikkelissa lähinnä yleisellä tavoitteiden tasolla. Ehdotusten tuominen käytäntöön - opetussuunnitelmiin ja oppitunneille - vaatii jatkotyötä. Perustelujen lisäksi artikkelissa kuitenkin esitettiin myös joitain kokemuksia konkreettista opetusmenetelmistä. I SEE -hankkeen opintojaksoilla opiskelijat ovat pitäneet erityisen 
tehokkaina ja voimaannuttavina niitä tulevaisuudentutkimuksen inspiroimia harjoitteita, joissa kehitettiin toivottavia tulevaisuusskenaarioita ja sovellettiin backcasting -menetelmää (Bishop ym., 2007; Robinson, 1990). Tällaiset aktiviteetit vaikuttavatkin hyviltä työkaluilta luonnontiedeopetukseen, joka tukee kestävyyskasvatusta, toimijuutta ja muutosta.

\section{Kiitokset}

Tuija Hyvättinen antoi arvokasta tukea tulevaisuudentutkimuksen kirjallisuuskatsaukseen ja esitti hyödyllisiä kommentteja ensimmäisen käsikirjoitusversion muihinkin osiin. Kiitän myös vertaisarvioijia kriittisestä palautteesta, joka auttoi selkeyttämään käsitteitä ja parantamaan artikkelin rakennetta. Arvostan erikoisnumeron toimittajien, Sirpa Tanin ja Essi Aarnio-Linnanvuoren, apua kieli- ja muotovirheiden korjailussa. Jos sellaisia vielä jäi, se on minun kontollani.

Kirjoitin artikkelin apurahakaudella, jonka mahdollisti Suomen Kulttuurirahasto (apuraha 00170575).

\section{Lähteet}

Ahvenharju, S., Minkkinen, M. \& Lalot, F. (2018). The five dimensions of Futures Consciousness. Futures, 104, 1-13. https://doi.org/10.1016/j.futures.2018.06.010

Apotheker, J., Blonder, R., Akaygun, S., Reis, P., Kampschulte, L. \& Laherto, A. (2017). Responsible Research and Innovation in secondary school science classrooms: experiences from the project Irresistible. Pure \& Applied Chemistry, 89(2), 211219. https://doi.org/10.1515/pac-2016-0817

Bandura, A. (1989). Human agency in social cognitive theory. American Psychologist, 44(9), 1175-1184. https://doi.org/10.1037/0003-066X.44.9.1175

Bell, W. (1997). Foundations of futures studies: Human science for a new era. Vol. 1, History, purposes and knowledge. New Brunswick, NJ: Transaction Publishers.

Bencze, L., Sperling, E. \& Carter, L. (2012). Students' research-informed socio-scientific activism: Re/visions for a sustainable future. Research in Science Education, 42(1), 129-148. https://doi.org/10.1007/s11165-011-9260-3

Bergmann, W. (1992). The problem of time in sociology: An overview of the literature on the state of theory and research on the 'Sociology of Time', 1900-82. Time \& Society, 1(1), 81-134. https://doi.org/10.1177/0961463X92001001007

Biesta, G. \& Tedder, M. (2007). Agency and learning in the lifecourse: Towards an ecological perspective, 39(2), 132-149. https://doi.org/10.1080/02660830.2007.11661545

Bishop, P., Hines, A. \& Collins, T. (2007). The current state of scenario development: An overview of techniques. Foresight, 9(1), 5-25. https://doi.org/10.1108/14636680710727516

Borup, M., Brown, N., Konrad, K. \& van Lente, H. (2006). The sociology of expectations in science and technology. Technology Analysis \& Strategic Management, 18(3-4), 285-298. https://doi.org/10.1080/09537320600777002

Branchetti, L., Cutler, M., Laherto, A., Levrini, O., Palmgren, E. K., Tasquier, G. \& Wilson, C. (2018). The I SEE project: An approach to futurize STEM education. Visions for Sustainability, 9, 10-26. https://doi.org/10.13135/2384-8677/2770

Buntting, C. \& Jones, A. (2015). Futures thinking in the future of science education. Teoksessa D. Corrigan, C. Buntting, J. Dillon, A. Jones \& R. Gunstone (toim.), The future in learning science: What's in it for the learner? (ss. 229-244). Dordrecht: Springer.

Carabelli, G. \& Lyon, D. (2016).Young people's orientations to the future: Navigating the present and imagining the future. Journal of Youth Studies, 19(8), 1110-1127. https://doi.org/10.1080/13676261.2016.1145641 


\section{Ainedidaktiikka 4(3) (2020)}

Carter, L. \& Smith, C. (2003). Re-visioning science education from a science studies and futures perspective. Journal of Future Studies, 7(4), 45-54.

Cook, J. (2016). Young adults' hopes for the long-term future: From re-enchantment with technology to faith in humanity. Journal of Youth Studies, 19(4), 517-532. https://doi.org/10.1080/13676261.2015.1083959

Cuzzocrea, V. \& Mandich, G. (2016). Students' narratives of the future: Imagined mobilities as forms of youth agency? Journal of Youth Studies, 19(4), 552-567. https://doi.org/10.1080/13676261.2015.1098773

Emirbayer, M. \& Mische, A. (1998). What is agency? The American Journal of Sociology, 103(4), 962-1023. https://doi.org/10.1086/231294

Erduran, S. (2020). Science education in the era of a pandemic. Science \& Education, 29(2), 233-235. https://doi.org/10.1007/s11191-020-00122-w

Erduran, S. \& Dagher, Z. (2014). Reconceptualizing the nature of science for science education. Scientific knowledge, practices and other family categories. Dordrecht: Springer.

European Commission (2015). Science education for responsible citizenship: Report to the European Commission of the expert group on science education. Luxembourg: Publications Office. Haettu osoitteesta http://dx.publications.europa.eu/10.2777/13004

Giddens, A. (1991). Modernity and self-identity: Self and society in the Late Modern Age. Stanford, CA: Stanford University Press.

Gilbert, J. K. (2006). On the nature of 'context' in chemical education. International Journal of Science Education, 28(9), 957-976. https://doi.org/10.1080/09500690600702470

Heikkilä, K., Nevala, T., Ahokas, I., Hyttinen, L. \& Ollila, J. (2017). Nuorten tulevaisuuskuvat 2067: Näkökulma suomalaisen yhteiskunnan kehittämiseksi. TUTU eJulkaisuja 6/2017. Turun yliopisto. http://urn.fi/URN:NBN:fi-fe2019052116250

Hicks, D. \& Holden, C. (1995). Visions of the future: Why we need to teach for tomorrow. Stoke-on-Trent: Trentham Books.

Higgins, K. (2016). Post-truth: a guide for the perplexed. Nature, 540(9). https://doi.org/10.1038/540009a

Hilppö, J. A., Rajala, A., Zittoun, T., Kumpulainen, K. \& Lipponen, L. (2017). Interactive dynamics of imagination in a science classroom. Front Learning Research, 4(4), 20-29. https://doi.org/10.14786/flr.v4i4.213

Hodson, D. (2003). Time for action: Science education for an alternative future. International Journal of Science Education, 25(6), 645-670. https://doi.org/10.1080/09500690305021

Hodson, D. (2011). Looking to the future: Building a curriculum for social activism. Rotterdam: Sense Publishers. https://doi.org/10.1007/978-94-6091-472-0

Hoffmann, R. \& Rainio, A. P. (2007). "It doesn't matter what part you play, it just matters that you're there." Towards shared agency in narrative play activity in school. Teoksessa R. Alanen \& S. Pöyhänen (toim.), Language in action: Vygotsky and Leontievian legacy today (ss. 308-328). Newcastle upon Tyne: Cambridge Scholars Publishing.

Hutchinson, F. (1996). Educating beyond violent futures. London: Routledge.

Inayatullah, S. (1998). Pedagogy, culture, and futures studies. American Behavioral Scientist, 42(3), 386-397. https://doi.org/10.1177/0002764298042003009

Jegstad, K. \& Sinnes, A. (2015). Chemistry teaching for the future: A model for secondary chemistry education for sustainable development. International Journal of Science Education, 37(4), 655-683. https://doi.org/10.1080/09500693.2014.1003988

Jones, A., Buntting, C., Hipkins, R., McKim, A., Conner, L. \& Saunders, K. (2012). Developing students' futures thinking in science education. Research in Science Education, 42(4), 687-708. https://doi.org/10.1007/s11165-011-9214-9

Kapon, S., Laherto, A. \& Levrini, O. (2018). Disciplinary authenticity and personal relevance in school science. Science Education, 102(5), 1077-1106. https://doi.org/10.1002/sce. 21458

Kokkonen, T. \& Laherto, A. (2018). Tiedeopetuksen muuttuvat tavoitteet - sisältötiedosta luonnontieteelliseen lukutaitoon. Ainedidaktiikka, 2(1), 20-38. https://doi.org/10.23988/ad.69250 


\section{Ainedidaktiikka 4(3) (2020)}

Laherto, A. (2010). An analysis of the educational significance of nanoscience and nanotechnology in scientific and technological literacy. Science Education International, 21(3), 160-175.

Laherto, A. (2013). Informing the development of science exhibitions through educational research. International Journal of Science Education, Part B: Communication and Public Engagement, 3(2), 121-143

https://doi.org/10.1080/21548455.2012.694490

Laherto, A. (2018). Research-based exhibition development: Illustrating the invisible nanoworld. Lumat: International Journal of Math, Science and Technology Education, 6(2), 103-125. https://doi.org/10.31129/LUMAT.6.2.323

Laherto, A., Kampschulte, L., de Vocht, M., Blonder, R., Akaygun, S. \& Apotheker, J. (2018). Contextualizing the EU's "Responsible Research and Innovation” policy in science education: A conceptual comparison with the Nature of Science concept and practical examples. EURASIA Journal of Mathematics, Science and Technology Education, 14(6), 2287-2300. https://doi.org/10.29333/ejmste/89513

Laininen, E. (2019). Transforming our worldview towards a sustainable future. Teoksessa J. W. Cook (toim.), Sustainabilty, human well-being, and the future of education (ss. 161-200). Helsinki: Sitra. https://doi.org/10.1007/978-3-319-78580-6_5

Lavonen, J., Laherto, A., Loukomies, A., Juuti, K., Kim, M., Lampiselkä, J. \& Meisalo, V. (2009). Enhancing scientific literacy through the industry site visit. Teoksessa S. Rodrigues (toim.), Multiple literacy and science education: ICTs in formal and informal learning environments (ss. 225-239). Hershey, PA: IGI / Information Science Reference. https://doi.org/10.4018/978-1-61520-690-2.ch013

Leccardi, C. (2012). Young people's representations of the future and the acceleration of time: A generational approach. Diskurs Kindheits- Und Jugendforschung Heft, 1, 59-73. https://nbn-resolving.org/urn:nbn:de:0168-ssoar-389412

Levinson, R. (2010). Science education and democratic participation: An uneasy congruence? Studies in Science Education, 46(1), 69-119. https://doi.org/10.1080/03057260903562433

Levrini, O., De Ambrosis, A., Hemmer, S., Laherto, A., Malgieri, M., Pantano, O. \& Tasquier, G. (2016). Understanding first-year students' curiosity and interest about Physics - Lessons learned from the HOPE project. European Journal of Physics, 38(2), 1-20. https://doi.org/10.1088/1361-6404/38/2/025701

Levrini, O., Tasquier, G., Barelli, E., Laherto, A., Palmgren, E., Branchetti, L. \& Wilson, C. (2020). Recognition and operationalization of future-scaffolding skills: Results from an empirical study of a teaching-learning module on climate change and futures thinking. Käsikirjoitus hyväksytty julkaistavaksi lehdessä Science Education.

Levrini, O., Tasquier, G., Branchetti, L. \& Barelli, E. (2019). Developing futurescaffolding skills through science education. International Journal of Science Education, 41(18), 2647-2674. https://doi.org/10.1080/09500693.2019.1693080

Lipponen, L. \& Kumpulainen, K. (2011). Acting as accountable authors: Creating interactional spaces for agency work in teacher education. Teaching and Teacher Education, 27(5), 812-819. https://doi.org/10.1016/j.tate.2011.01.001

Lloyd, D. \& Wallace, J. (2004). Imaging the future of science education: The case for making futures studies explicit in student learning. Studies in Science Education, 40(1), 139-177. https://doi.org/10.1080/03057260408560205

Lombardo, T. \& Cornish, E. (2010). Wisdom facing forward: What it means to have heightened future consciousness. The Futurist, 44(5), 34-42.

Lombardo, T. (2016). Future consciousness: The path to purposeful evolution - An introduction. World Futures Review, 8(3), 116-140. https://doi.org/10.1177/1946756716673636

Lotz-Sisitka, H., Wals, A. E., Kronlid, D. \& McGarry, D. (2015). Transformative, transgressive social learning: Rethinking higher education pedagogy in times of systemic global dysfunction. Current Opinion in Environmental Sustainability, 16, 73-80. https://doi.org/10.1016/j.cosust.2015.07.018

Masini, E. (1993). Why future studies? London: Grey Seal.

Mead, G. H. (1932). The philosophy of the present. Chicago: University of Chicago Press.

Mogensen, F. \& Schnack, K. (2010). The action competence approach and the 'new' discourses of education for sustainable development, competence and quality criteria. Environmental Education Research, 16(1), 59-74.

https://doi.org/10.1080/13504620903504032 


\section{Ainedidaktiikka 4(3) (2020)}

Niemeläinen, J. (2020). "Kansalaiset huomaavat, miten tappavia epäpätevyyden seuraukset voivat olla" - tutkija Yascha Mounk ei kuitenkaan usko koronaviruksen aiheuttavan laajoja muutoksia. Helsingin Sanomat, 27.4.2020. Haettu osoitteesta https://www.hs.fi/ulkomaat/art-2000006487841.html

OECD (2018). The future of education and skills: Education 2030. OECD Education Working Papers.

OECD (2019). PISA 2018 science framework. PISA 2018 assessment and analytical framework (ss. 97-117). Paris: OECD Publishing. https://doi.org/10.1787/f30da688-en

Ojala, M. (2012). Hope and climate change: The importance of hope for environmental engagement among young people. Environmental Education Research, 18(5), 625-642. https://doi.org/10.1080/13504622.2011.637157

Ono, R. (2003). Learning from young people's image of the future: A case study in Taiwan and the US. Futures, 35(7), 737-758. https://doi.org/10.1016/S0016-3287(03)00025-9

Opetushallitus (2004). Perusopetuksen opetussuunnitelman perusteet 2004. Helsinki: Opetushallitus.

Opetushallitus (2014). Perusopetuksen opetussuunnitelman perusteet 2014. Helsinki: Opetushallitus.

Opetushallitus (2019). Lukion opetussuunnitelman perusteet 2019. Helsinki: Opetushallitus.

Osborne, J. \& Collins, S. (2000). Pupils' and parents' views of the school science curriculum. The School Science Review, 82(298), 23-31.

Osborne, J., Erduran, S. \& Simon, S. (2004). Enhancing the quality of argumentation in school science. Journal of Research in Science Teaching, 41(10), 994-1020. https://doi.org/10.1002/tea.20035

Paige, K. \& Lloyd, D. (2016). Use of future scenarios as a pedagogical approach for science teacher education. Research in Science Education, 46(2), 263-285. https://doi.org/10.1007/s11165-015-9505-7

Palmgren, E., Laherto, A., Tuominen, K. \& Puranen, T. (2019). Kvanttitietokoneet ja tietotekniikan tulevaisuus. Helsinki: Helsingin yliopisto / I SEE -projekti. http://hdl.handle.net/10138/311369

Van Poeck, K. (2019). Environmental and sustainability education in a post-truth era: An exploration of epistemology and didactics beyond the objectivism-relativism dualism. Environmental Education Research, 25(4), 472-491.

https://doi.org/10.1080/13504622.2018.1496404

Rasa, T., Laherto, A. \& Palmgren, E. (2020). Broadening perceptions of future and agency: students' experiences from a module on futures thinking and quantum computing. Käsikirjoitus valmisteilla.

Rickards, L., Ison, R., Fünfgeld, H. \& Wiseman, J. (2014). Opening and closing the future: Climate change, adaptation, and scenario planning. Environment and Planning C: Government and Policy, 32(4), 587-602. https://doi.org/10.1068/c3204ed

Roberts, D. A. (2007). Scientific literacy/science literacy. Teoksessa S. K. Abell \& N. G. Lederman (toim.), Handbook of research on science education (ss. 729-780). Mahwah, NJ: Lawrence Erlbaum Associates.

Roberts, D. A. \& Bybee, R. W. (2014). Scientific literacy, science literacy, and science education. Teoksessa N. G. Lederman \& S. K. Abel (toim.), Handbook of research on science education, Vol. II (ss. 545-558). New York: Routledge.

Robinson, J. B. (1990). Futures under glass: A recipe for people who hate to predict. Futures, 22(8), 820-842. https://doi.org/10.1016/0016-3287(90)90018-D

Rocard, M., Csermely, P., Jorde, D., Lenzen, D., Walwerg-Heriksson, H. \& Hemmo, V. (2007). Science education now: A renewed pedagogy for the future of Europe. Brussels: European Commission, Directorate-General for Research, Science, Economy and Society. Haettu osoitteesta https://ec.europa.eu/research/science-society/document_library/pdf_06/report-rocard-on-science-education en.pdf

Rosa, H. (2013). Social acceleration: A new theory of modernity. New York: Columbia University Press. https://doi.org/10.7312/rosa14834

Roth, W. \& Lee, S. (2004). Science education as/for participation in the community. Science Education, 88(2), 263-291. https://onlinelibrary.wiley.com/doi/abs/10.1002/sce.10113 


\section{Ainedidaktiikka 4(3) (2020)}

Rubin, A. (2013). Hidden, inconsistent, and influential: Images of the future in changing times. Futures, 45, S38-S44. https://doi.org/10.1016/j.futures.2012.11.011

Sharpe, B., Hodgson, A., Leicester, G., Lyon, A. \& Fazey, I. (2016). Three horizons: A pathways practice for transformation. Ecology and Society, 21(2), 47. http://dx.doi.org/10.5751/ES-08388-210247

Sirén, V. (2020). Totuus palasi totuudenjälkeiseen aikaan - Riittääkö koronaviruksen herättämä rationaalisuuden aalto pelastamaan maailmanpolitiikan? Helsingin Sanomat, 15.4.2020. Haettu osoitteesta https://www.hs.fi/ulkomaat/art-2000006474652.html

Sjöström, J., Frerichs, N., Zuin, V. \& Eilks, I. (2017). Use of the concept of Bildung in the international science education literature, its potential, and implications for teaching and learning. Studies in Science Education, 53(2), 165-192. https://doi.org/10.1080/03057267.2017.1384649

Stamer, I., Pönicke, H., Tirre, F., Laherto, A., Höffler, T., Schwarzer, S. \& Parchmann, I. (2020). Development \& validation of scientific video vignettes to promote perception of authentic science in student laboratories. Research in Science \& Technological Education, 38(2), 168-184. https://doi.org/10.1080/02635143.2019.1600491

Stuckey, M., Hofstein, A., Mamlok-Naaman, R. \& Eilks, I. (2013). The meaning of 'relevance' in science education and its implications for the science curriculum. Studies in Science Education, 49(1), 1-34. https://doi.org/10.1080/03057267.2013.802463

Tasquier, G., Branchetti, L. \& Levrini, O. (2019). Frantic standstill and lack of future: How can science education take care of students' distopic perceptions of time? Teoksessa E. McLoughlin, O. Finlayson, S. Erduran \& P. Childs (toim.), Bridging research and practice in science education: Contributions from science education research (ss. 205-224). Dordrecht: Springer. https://doi.org/10.1007/978-3-030-17219-0_13

Tasquier, G., Levrini, O., Laherto, A., Wilson, C. \& Palmgren, E. (2018). The challenge of working with the future within STEM education. Teoksessa J. Kay \& R. Luckin (toim.), Rethinking learning in the digital age: Making the learning sciences count, 13th International Conference of the Learning Sciences (ICLS) 2018, Volume 3 (ss. 1441-1442). London: International Society of the Learning Sciences. http://ccl.northwestern.edu/2018/ICLS2018Volume3 proceedings.pdf

Timonen, V. (2020). Elimme hillittömän kasvun aikaa, kunnes koronavirus pysäytti meidät, sanoo sosiaaliantropologi Thomas Hylland Eriksen. Helsingin Sanomat, 26.4.2020. Haettu osoitteesta https://www.hs.fi/ulkomaat/art-2000006487172.html

Tolppanen, S., Aarnio-Linnanvuori, E., Cantell, H. \& Lehtonen, A. (2017). Pirullisen ongelman äärellä - Kokonaisvaltaisen ilmastokasvatuksen malli. Kasvatus, 48(5), $256-468$.

Unesco (2017). Education for Sustainable Development Goals: Learning objectives. Paris: Unesco. Haettu osoitteesta https://unesdoc.unesco.org/ark:/48223/pf0000247444

Virtanen, J. (2020). "Populismin myrkky" voi imeytyä yhteiskuntaan, jos käpertyminen jää päälle - Filosofi Bernard-Henri Lévy aloittaa HS:n juttusarjan, joka tarkastelee maailmaa koronan jälkeen. Helsingin Sanomat, 25.4.2020. Haettu osoitteesta https://www.hs.fi/ulkomaat/art-2000006486421.html

de Vocht, M. \& Laherto, A. (2017). Profiling teachers based on their professional attitudes towards teaching Responsible Research and Innovation. European Journal of Science and Mathematics Education, 5(3), 271-284.

de Vocht, M. Laherto, A. \& Parchmann, I. (2017). Exploring teachers' concerns about bringing Responsible Research and Innovation to European science classrooms. Journal of Science Teacher Education, 28(4), 326-346. https://doi.org/10.1080/1046560X.2017.1343602

Voros, J. (2003). A generic foresight process framework. Foresight, 5(3), 10-21. https://doi.org/10.1108/14636680310698379

Wiek, A., Withycombe, L. \& Redman, C. (2011). Key competencies in sustainability: A reference framework for academic program development. Sustainability Science, 6(2), 203-218. https://doi.org/10.1007/s11625-011-0132-6 
Ainedidaktiikka 4(3) (2020)

Zeidler, D. L., Sadler, T. D., Simmons, M. L. \& Howes, E. V. (2005). Beyond STS: A research-based framework for socioscientific issues education. Science Education, 89(3), 357-377. https://doi.org/10.1002/sce.20048 